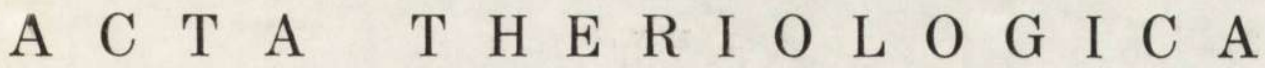

\author{
Elżbieta W O Ł K
}

\section{The Blood Leukocytes in the Postnatal Development of the Root Vole}

[With 1 Table \& 2 Figs]

\begin{abstract}
Examination was made of 115 root voles Microtus oeconomus, obtained from long-term laboratory breeding, 100 of which were $1-61$ days, and $15-12-22$ months old. The total number of leukocytes in $1 \mathrm{~mm}^{3}$ of blood were counted anc the percentage and absolute numbers of their different forms determineá. The total number of leukocytes increases during the first weeks of the root vole's life, this increase being most intensive from the 1 st to the 13 th day. The absolute numbe: of lymphocytes and their percentage in the blond, and also the absolute number of neutrophils increase during the first three weeks of the animals' life, while the percentage of neutrophils decreases. Only a poor lymphocyte blood profile was found in animals from 12-22 months old, since the percentage of lymphocytes decreased and that of neutrophils increased. Consequently the $L / N$ index, which increases during the first weeks of life, is lower in the group of adult animals. No sex differences were found.
\end{abstract}

\section{INTRODUCTION}

The paper presented below forms the second stage of hematological studies on the root vole, Microtus oeconomus (P a 11 a s, 1776). Previous studies had been made of changes in the elements of the erythrceyte system in the postnatal development of this rodent ( $\mathrm{W}$ o $\mathrm{k}, 1970 \mathrm{~b}$ ). The changes connected with the root vole's age in the number and composition of leukocytes of peripheral blood were compared with analogical data for other species of rodents ( $\mathrm{Pujman,} P$ rokopova \& Reichlova, $1955 ;$ Kostelecka-Myrcha \& Myrcha, 1966, $1967 ;$ Kozakevič, 1968; Fournon, Mathieu, Isoard, Germain \& Font anges, 1970). 


\section{MATERIAL AND METHODS}

Studies were made of 115 root voles obtained from long-term laboratory breeding in the Mammals Research Institute at Białowieża, 100 of which ranged in age from $1-61$ days. The data obtained were compared with the group of adults aged from 12-22 months. Blood was taken from the jugular vein under ether anaesthesia and diluted with Türk's fluid. In order to eliminate the possible effet of handling (W o $1 \mathrm{k}, 1970 \mathrm{a}$ ) and time of the day on the peripheral blood leukocytes, the animals were anaesthetized between $9^{\circ \circ}-11^{\circ \circ}$ a. m. and immediately after removing them from cages. Leukocytes were counted in a Bürker chamber, and their various forms identified in smears stained by Pappenheim's method. When differentiating between the various forms of leukocytes the division used by certain authors into large and small lymphocytes was omitted, as this division has been recognized as unjustified (M i c h a łow ski, 1970).

The dependence of the number of the leukocytes and their various forms on the animals' age was characterized by means of rectilinear regression equations. The significance of the slope of regression lines was checked by the $t$ test. Selected age groups of animals were described by means of average values and confidence intervals. The significance of differences between these averages was checked by the $t$ test for two independent groups.

The material was not divided into groups according to sex as no differences were found between males and females in the number of leukocytes and their various forms.

\section{RESULTS AND DISCUSSION}

Reticular cells, later only sporadically encountered, occur fairly numerously in blood smears from one day-old root voles.

The total number of leukocytes increases during the first few weeks of the animal's life, increase being particularly intensive up to approximately the 13th day of life (Fig. 1A). Evidence of this is provided by the highly significant inclination of the regression line describing increase in the number of leukocytes at this period of the animal's life in relation to the age $(\mathrm{P}<.001)$. The difference in number of leukocytes is also significant $(.02<\mathrm{P}<.05)$ between groups of redents from $11-15$ and 25-31 days old, and thus its increase continues, though less dynamically. Later this value does not undergo change, as is shown by comparison with the group of animals 12-22 months old (Table 1).

Increase in the number of leukocytes up to 10th day of life was observed in Microtus socialis ( $\mathrm{R} \circ \mathrm{g}$ a $\mathrm{t} \mathrm{ko}, 1970$ ) and also similarly in rats (Pujman et al., 1955). In Pitymys subterraneus (KosteleckaMyrcha \& Myrcha, 1966b) and in Citellus fulvus (Kozakevič, 1968), however, the number of leukocytes gradually decreases with age, while in Clethrionomys glareolus ( $\mathrm{Kos}$ ele $\mathrm{cka}-\mathrm{Myr} \mathrm{cha} \& \mathrm{Myr}-$ $\mathrm{ch} \mathrm{a}, 1967)$ and Microtus arvalis ( $\mathrm{R} \circ \mathrm{g} \mathrm{at} \mathrm{ko}, 1970)$ this value remains almost unchanging. 


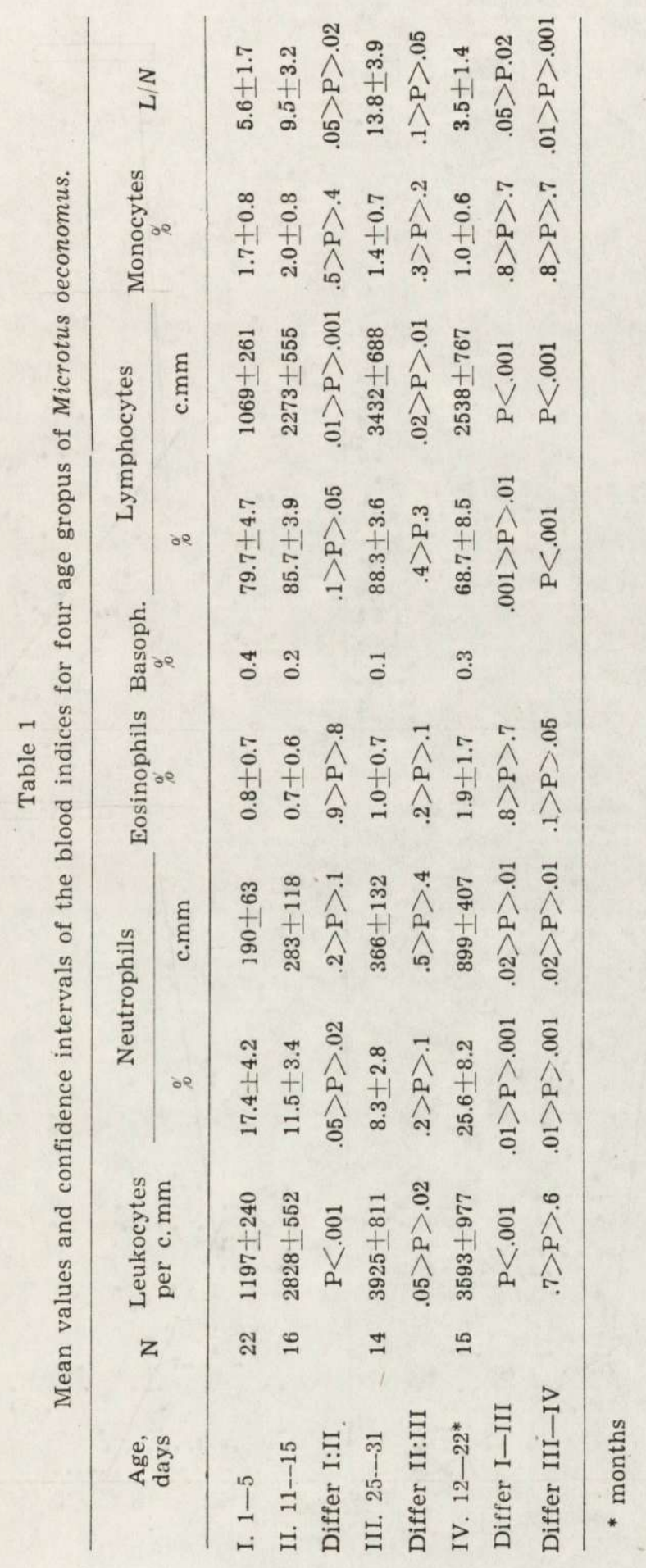




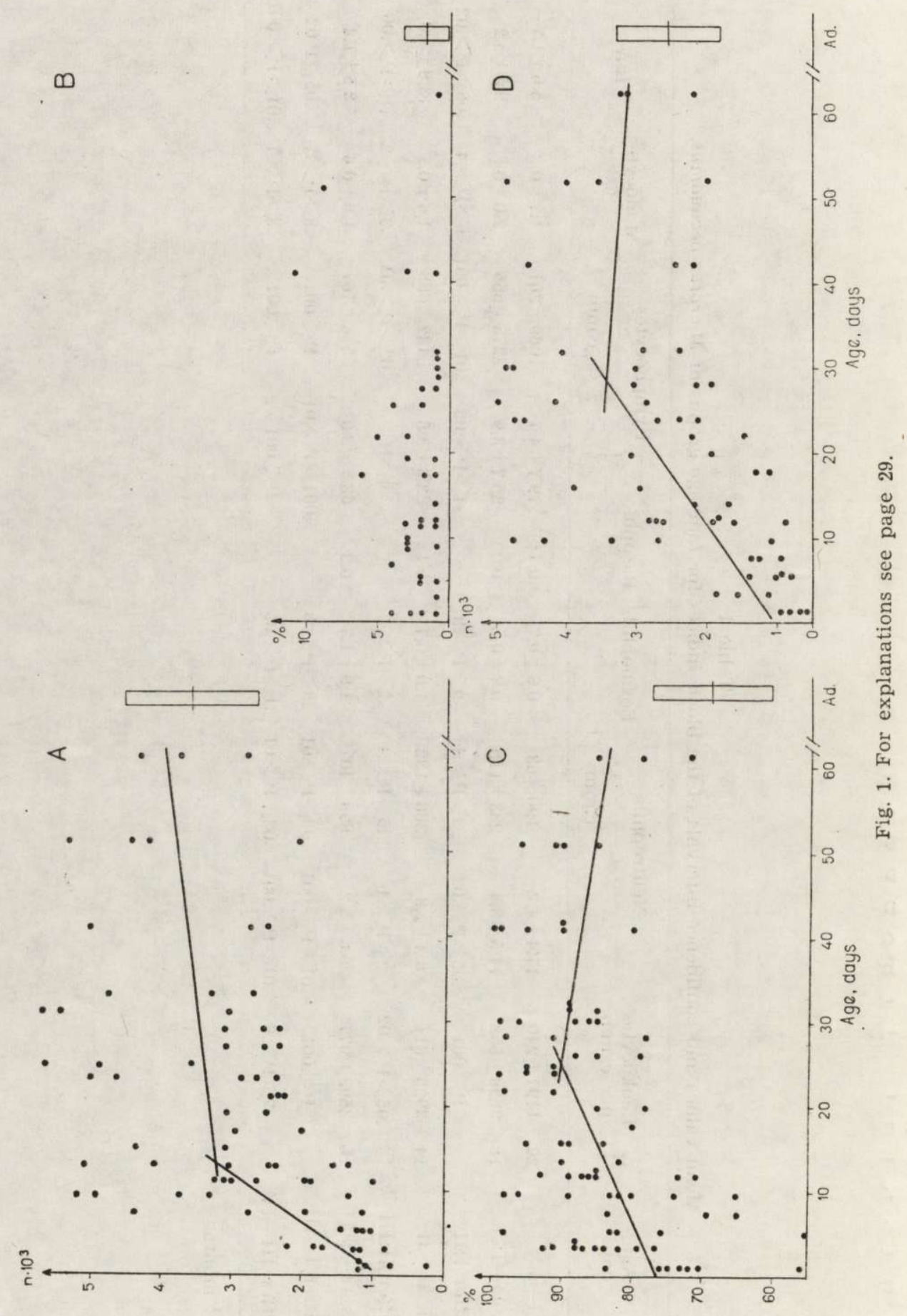


Intensive increase in the number of leukocytes during the first 13 days of life of root voles is undoubtedly connected with the rate of their development.

The total number of leukocytes in $M$. oeconomus is affected almost exclusively by two of their forms: lymphocytes and neutrophils. Eosinophils, monocytes and basophils form a negligible percentage, and their numbers do not significantly alter (Fig. 1B, Table 1). In this connection detailed consideration was given to changes, connected with the animals' age, in the number of lymphocytes and neutrophils. Both the percentage of lymphocytes and their absolute number in $1 \mathrm{~mm}^{3}$ of blood change in an analogical way. Both these values increase up to about the 25th day of life, as shown by the significance of the slope of the regression lines illustrating these changes $(.001<\mathrm{P}<.01)$. The regression lines for the animals 25 to 61 day old do not deviate significantly from the age axis (Fig. 1C and D). In older animals, however, both these values distinctly decrease, since differences between average values describing the number of lymphocytes in 25-31 day old and $12-22$ months old root voles are highly significant $(\mathrm{P}<.001$; Table 1$)$.

The percentage of neutrophils in blood changes in an opposite way it decreases in animals from the time of birth to about the 50th day of life (Fig. 2A, Table 1). It must be emphasised here that when calculating the regression equation data were omitted for animals 61 days old, as markedly differing from the general tendency and agreeing with data for adult root voles. The percentage of neutrophils in this group is distinctly greater $(.001<\mathrm{P}<.01)$ (Table 1 ).

At the same time as the percentage of neutrophils decreases their absolute number constantly, although only slightly, increases. Differences between groups of animals aged $1-5$ and $25-31$, like those between animals $25-31$ days old and adults, are statistically significant (in both cases $.01<$ P $<.02$; Fig. $2 \mathrm{~B}$, Table 1 ).

Changes in the $L / N$ index follow logically from changes in the numbers of lymphocytes and neutrophils. As the percentage of lymphocytes in the

Fig. 1. Changes of average morphological indices of blood in $M$. oeconomus during postnatal development. Averages and confidence intervals for adult animals (Ad.) are given at right side of the diagram.

A. Total leukocyte count:

B. Percentage of eosinophils.
1) $y=887.6+178.6 x$
2) $y=3065.0+15.1 x$.

C. Percentage of lymphocytes:

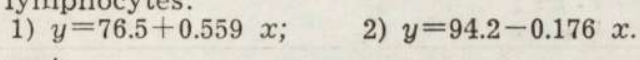

D. Lymphocyte count:
1) $y=1103.3+84.9 x$;
2) $y=3724.2-10.1 x$. 


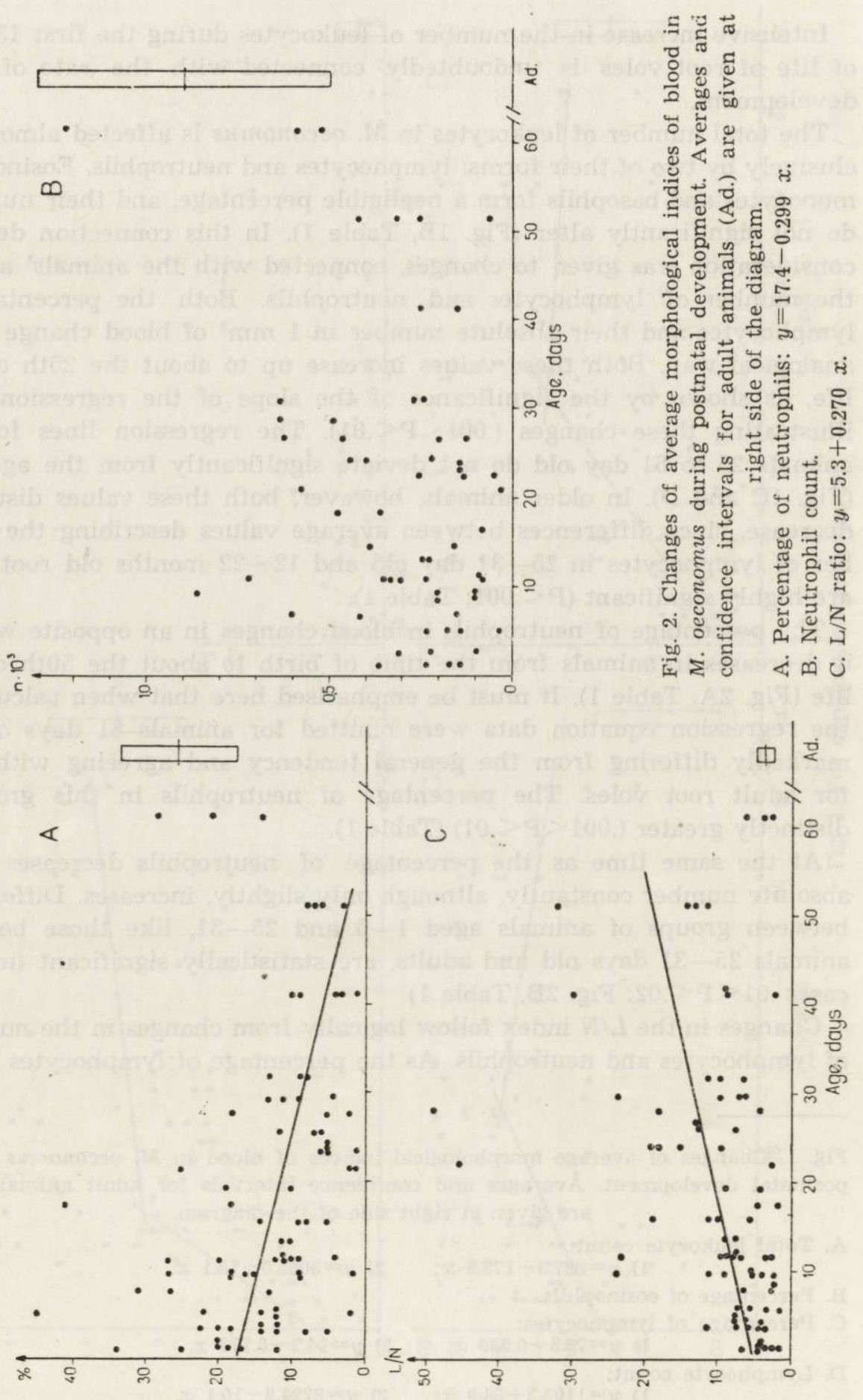


blood increases during the first weeks of life, and that of neutrophils decreases $-L / N$ value also increases during the animal's life (Fig. 2C. Table 1). It is not until animals are from $12-22$ months old that this index exhibits significant reduction $(.001<\mathrm{P}<.01)$ (Table 1). Data for animals 61 days old have been omitted when calculating the regression equation for course of variations in the $L / N$ index since they are at variance with its general tendency to increase, and similar to values characterizing adult animals.

The correlation found in root voles, and connected with age, between lymphocytes and neutrophils constitutes a further confirmation of the regularity formulated by $\mathrm{Nikitin} \& \mathrm{Skorobogatova}$ (1951). Explanation of the interesting phenomenon of increase in the percentage of lymphocytes and the decrease in the number of neutrophils accompanying it may be connected with the defensive function of lymphocytes, the role of which becomes far more important in the early postnatal period of the animals' life.

The leukogram of animals $12-22$ months old is considered as a kind of normal condition in this species (Table 1). Comparison with other systematically closely related rodents points to the maximum similarity between the average values of the leukogram of the root vole and the corresponding data characterizing the blood of Lagurus lagurus (K o s t ele c k a - M y r c ha, 1966a). The lymphocytic character of blood, so typical of other representatives of the Microtidae family, is also faintly expressed in this species.

\section{REFERENCES}

1. Fournon'S., Mathieu J., Isoard P., Germain D. \& Fontanges R., 1970: Etude de l'èvolution de la numeration et de la formule sanguine de la souris $\mathrm{BALB} / \mathrm{c}$ pendant les premiers mois de la vie. C. r. Soc. biol., 164, 1: $161-165$.

2. Kostelecka-Myrcha A. \& Myrcha A., 1966a: Studies on blood leukocytes of some Microtidae under laboratory conditions. Bull. Acad. Pol. Sci. Cl. II, $14,5: 351-353$.

3. Kostelecka-Myrcha A. \& Myrcha A., 1966b: Studies on the blood leukocytes in the postnatal development of Pitymys subterraneus (de SélysLong c hamps, 1835) (Mammalia, Microtidae). Bull. Acad. Pol. Sci. Cl. II, 14, 6: $419-423$.

4. Kostelecka-Myrcha A \& Myrcha A., 1967: Variability of the leukocyte count in the blood of bank vole, Clethrionomys glareolus (Schreber, 1870) under laboratory conditions. Bull. Acad. Pol. Sci. Cl. II, 15, 11: 675-682.

5. Kozakevi č V. P., 1968: Sezonnye i vozrastnye izmenenija sostava beloj krovi u suslikov i tuškančikov. Zool. Ž., 47, 10: 1533-1538.

6. Micha lowski A., 1970: Kilka uwag na temat klasyfikacji limfocytów. Post. hig. i med. dośw., 24, 1: 55-61. 
7. Nikitin V. N. \& Skorobogatova A. M., 1951: Obščie zakonomernosti vozrastnyh izmenenij leikocitarnoj kartiny krovi vysših pozvonočnyh. Žurn. Obšč. Biol., 12, 4: 287-295.

8. Pujman V., Prok opova S. \& Reichlova R., 1955: Krevni obraz krysy. Acta Soc. Bohemoslov., 19, 2: 175-182.

9. Rogatko I. V., 1970: Vozrastnaja izmenčivost' gematologičeskih pokazatelej u obyknovennoj i obščestvennoj polevok. Vest. zool., 3: 21-25.

10. W o lk E., 1970a: The effect of handling on the blood indices of the pine vole (Pitymys subterraneus). Bull. Acad. Pol. Sci. Cl. II, 18, 1: 43-46.

11. Wo $1 \mathrm{k}$ E., 1970b: Erythrocytes, haemoglobin and haematocrit in the postnatal development of the root vole. Acta theriol., 15, 19: 283-293.

Accepted, December 2, 1971.

Mammals Research Institute,

Polish Academy of Sciences,

Białowieża, woj. Białystok.

\section{Elżbieta WOEK}

\section{LEUKOCYTY KRWI W ROZWOJU POSTNATALNYM NORNIKA PÓ£NOCNEGO}

\section{Streszczenie}

U 115 norników, Microtus oeconomus badano zmiany w liczbie i składzie leukocytów krwi obwodowej, związane $\mathrm{z}$ wiekiem. Norniki te pochodziły z kilkuletniej hodowli laboratoryjnej. Ogólną liczbę leukocytów obliczano w komorze Bürkera, a ich poszczególne formy oznaczano na preparatach barwionych metodą Pappenheima. Wykreślono proste regresji, obrazujące zmiany w liczbie i składzie leukocytów w ciągu życia norników.

Wyraźnie limfocytowy profil krwi młodych norników zanika u,zwierząt 12-22 miesięcznych (Tabela 1). W rozwoju postnatalnym ogólna liczba leukocytów rośnie w ciągu pierwszych tygodni życia (Tabela 1). Wzrost ten jest najbardziej dynamiczny do około 13 dnia życia. Składa się na niego głównie zwiększanie się zarówno liczby bezwzględnej jak i procentowej zawartości limfocytów (Fig. 1C, D). Natomiast przy wzroście bezwzględnej liczby neutrofilów, maleje ich procentowy udział (Fig. 2A, B). Zwiększa się on wyraźnie- dopiero $u$ dorosłych zwierząt (Tabela 1). Skutkiem tych zmian indeks $L / N$ zwiększa się w ciągu życia zwierząt, obniżając się wyraźnie w grupie norników 12-22 miesięcznych (Fig. 2C, Tabela 1). Zmiany w kształtowaniu się białokrwinkowego obrazu krwi przebiegają jednakowo u obu płci. 